\title{
Dealing With Snakes in Florida's Residential Areas - Introduction ${ }^{1}$
}

Steve A. Johnson andMonica E. McGarrity ${ }^{2}$

As Florida's human population continues to grow, remaining green spaces continue to be fragmented into even smaller areas of natural habitat. The outcome of this insidious process is the creation of small pockets of wildlife habitat in an otherwise urban or suburban landscape. As a result, encounters with snakes in residential areas are increasingly likely to occur. Despite the fear that many people experience when they encounter a snake, there is absolutely no cause for alarm when the encounter involves a harmless, non-venomous snake.

Fortunately, most encounters between people and snakes in residential areas involve one of Florida's 39 native species of non-venomous snakes. Despite the high diversity of harmless snakes in Florida, many of these species do not thrive in residential areas, and of those that do, some are very secretive and are rarely seen by people.

Interactions between people and venomous snakes in residential areas are much less common than those involving non-venomous species, and the risk of snakebite (venomous or non-venomous) is extremely small. There are only six species of venomous snakes in Florida, and only four of these species are found south of the Gainesville area.

Attempting to harass, handle, or kill venomous snakes significantly increases your chances of being bitten, so it is best to adopt a "leave it be" attitude for all venomous snakes. This also can help to prevent the needless killing of harmless snake species. If you are not $100 \%$ sure of the identity of a snake just "leave it be."

Snakes play important roles in Florida's ecosystems and help to control rodents (common disease-carrying residential pests) and even other snakes. Some non-venomous species, like the Eastern Indigo Snake and kingsnakes, eat venomous snakes! Snakes also serve as important prey for birds and other animals. Sadly, habitat loss and fragmentation associated with development are serious threats for many snake species, as is wanton persecution by people who are ignorant of the important roles snakes play in Florida's ecology or who cannot confidently identify snakes. Several species of Florida's snakes are now considered threatened or endangered, and even commonly seen species that seem to thrive in

1. This document is WEC 219, the first in a 4-part series entitled "Dealing with Snakes in Florida's Residential Areas", of the Department of Wildlife Ecology and Conservation, University of Florida/IFAS. First published July 2007. Accompanying documents by Dr. Johnson related to dealing with snakes in a variety of settings are available through the University of Florida/EDIS at http://edis.ifas.ufl.edu/TOPIC_A23708620. A free PowerPoint presentation (with speaking notes) on the topic of venomous snake safety is available upon request from Steve A. Johnson by E-mail - tadpole@ufl.edu.

2. Steve A. Johnson - Department of Wildlife Ecology and Conservation and Gulf Coast Research and Education Center, University of Florida IFAS/Plant City Campus, 1200 North Park Road, Plant City, FL 33563

Monica E. McGarrity - Gulf Coast Research and Education Center, University of Florida IFAS/Plant City Campus, Plant City, FL

The Institute of Food and Agricultural Sciences (IFAS) is an Equal Opportunity Institution authorized to provide research, educational information and other services only to individuals and institutions that function with non-discrimination with respect to race, creed, color, religion, age, disability, sex, sexual orientation, marital status, national origin, political opinions or affiliations. U.S. Department of Agriculture, Cooperative Extension Service, University of Florida, IFAS, Florida A. \& M. University Cooperative Extension Program, and Boards of County Commissioners Cooperating. Millie Ferrer, Interim Dean 
urban areas are at risk of being killed by pets, lawnmowers, vehicles, or residents who are unfamiliar with Florida's snakes.

In residential areas where human-snake encounters are likely, we recommend a three part proactive approach for coexisting safely with snakes:

1. Education - Learn to identify commonly encountered non-venomous and venomous snakes, and teach others - especially children! Learn to understand and respect snakes, and to be safe in areas frequented by snakes.

2. Prevention - Take steps to discourage snakes from entering homes and high-use areas of residential properties, warn children and pets to stay away from areas frequented by snakes, and adopt a "leave it be" attitude.

3. Emergency Plan - Establish an emergency action plan for the unlikely event that a resident, child, or pet is bitten by a venomous snake.

This document is the first in a series of four documents by Dr. Steve Johnson and Monica McGarrity that provide information to Florida's residents on how to identify snakes that are commonly encountered in residential settings, how to prevent negative encounters from occurring in the first place, and how to respond in the unlikely event that someone is bitten by a snake. Anyone living in Florida, especially people new to the state, will find these documents useful. These documents are available online through UF/IFAS Extension Electronic Data Information Source.

1. Dealing With Snakes in Florida's Residential Areas - Introduction (http://edis.ifas.ufl.edu/UW257)

2. Dealing With Snakes in Florida's Residential Areas - Identifying Commonly Encountered Snakes (http://edis.ifas.ufl.edu/UW258)

3. Dealing With Snakes in Florida's Residential Areas - Preventing Encounters (http://edis.ifas.ufl.edu/UW260)
4. Dealing With Snakes in Florida's Residential Areas - Emergency Planning (http://edis.ifas.ufl.edu/UW261)

\section{Additional Resources}

\section{$\underline{\text { Hotline Numbers: }}$}

Poison Control Hotline: 1-800-222-1222

American Society for the Prevention of Cruelty to Animals (ASPCA) Poisoning Hotline: 1-888-426-4435 (charges may apply)

\section{Good Books on Florida Snakes:}

Conant, R., and J. Collins. 1998. Peterson Field Guide to Reptiles and Amphibians of Eastern and Central North America, 3rd edition. Boston: Houghton Mifflin Company.

Carmichael, P., and W. Williams. 2004. Florida's Fabulous Reptiles and Amphibians. Tampa: World Publications.

Tennant, A. 2003. Snakes of North America: Eastern and Central Regions. revised edition. Houston: Lone Star Books.

\section{Snake Resources on the World Wide Web:}

Johnson, S.A. 2005. Dealing with Venomous Snakes in Florida Schoolyards Series.

WEC199-202. Gainesville: Institute of Food and Agricultural Services.

http://edis.ifas.ufl.edu/

TOPIC_SERIES_Dealing_with_Venomous_Snakes_i n_Florida_School_Yards

Johnson, S.A., and M.E. McGarrity. "Black Snakes": Identification and Ecology. WEC214. Gainesville: Institute of Food and Agricultural Services. 2006. http://edis.ifas.ufl.edu/UW251

Florida Museum of Natural History-Online guide to Florida snakes:

http://www.flmnh.ufl.edu/herpetology/FLGUIDE/ onlineguide.htm

\section{Florida Fish and Wildlife Conservation Commission snake page:http://www.myfwc.com/critters/snakes.asp}


Partners in Amphibians and Reptile

Conservation (PARC) site:

http://www.parcplace.org/index.html

Snake Handling Equipment:

Midwest Tongs - http://www.tongs.com (we

recommend their Gentle Giant tongs)

Tomahawk Live Trap -

http://www.tomahawklivetrap.com (we recommend

their 60" Super Tube tongs with rubber cushions) 